\title{
In situ soft sediment nutrient enrichment: A unified approach to eutrophication field experiments
}

\author{
Emily J. Douglas ${ }^{\mathrm{a}, *}$, Conrad A. Pilditch ${ }^{\mathrm{a}}$, Laura V. Hines ${ }^{\mathrm{a}}$, Casper Kraan ${ }^{\mathrm{b}, 1}$, Simon F. Thrush ${ }^{\mathrm{c}}$ \\ a School of Science, University of Waikato, Private Bag 3105, Hamilton 3240, New Zealand \\ b National Institute of Water and Atmospheric Research, P.O. Box 11-115, Hamilton 3251, New Zealand \\ c Institute of Marine Science, University of Auckland, Private Bag 92019, Auckland 1142, New Zealand
}

\section{A R T I C L E I N F O}

\section{Article history:}

Received 12 November 2015

Received in revised form 9 June 2016

Accepted 27 June 2016

Available online 4 July 2016

\section{Keywords:}

Benthic

Intertidal

Macrofauna

Pore water

Enrichment method

Fertiliser

\begin{abstract}
A B S T R A C T
Adding fertiliser to sediments is an established way of studying the effects of eutrophication but a lack of consistent methodology, reporting on enrichment levels, or guidance on application rates precludes rigorous synthesis and meta-analysis. We developed a simple enrichment technique then applied it to 28 sites across an intertidal sandflat. Fertiliser application rates of 150 and $600 \mathrm{~g} \mathrm{~N} \mathrm{~m}^{-2}$ resulted in pore water ammonium concentrations respectively 1-110 and 4-580 $\times$ ambient, with greater elevations observed in deeper $(5-7 \mathrm{~cm})$ than surface $(0-2 \mathrm{~cm})$ sediments. These enrichment levels were similar to eutrophic estuaries and were maintained for at least seven weeks. The high between-site variability could be partially explained by the sedimentary environment and macrofaunal community (42\%), but only at the high application rate. We suggest future enrichment studies should be conducted in situ across large environmental gradients to incorporate real world complexity and increase generality of conclusions.
\end{abstract}

(c) 2016 Elsevier Ltd. All rights reserved.

\section{Introduction}

Nutrient processing is deemed one of the most valuable ecosystem services globally and the majority of this occurs in coastal soft sediments (Costanza et al., 1997). This ecosystem service influences the supply and flux of nutrients within and between marine habitats and through denitrification in particular, can alleviate problems such as the loss of ecosystem functionality and biodiversity associated with excess nutrients. Indeed, excessive nutrient loading and eutrophication are stressing coastal marine environments throughout the world (Levin et al., 2015). The overabundance of nitrogen in particular the (nutrient usually limiting production (Herbert, 1999; Howarth and Marino, 2006)) causes changes in biomass, structure, and functioning of coastal communities and food webs (Abreu et al., 2006; Howarth et al., 2011; Rabalais et al., 2014). Yet, despite being of paramount importance to global environmental wellbeing, nutrient processing in soft sediments is still poorly understood and response to perturbations are rarely tested experimentally in situ. Reliable techniques are needed to empirically test the effects of excess nutrients, and its interactions with other stressors in real world settings that embrace ecological complexity,

\footnotetext{
* Corresponding author.

E-mail address: emilydouglas@outlook.com (E.J. Douglas).

1 Present address: Alfred Wegener Institute, Helmholtz Centre for Polar and Marine Research, Department of Functional Ecology, Am Handelshafen 12, 27570 Bremerhaven, Germany.
}

and thereby allow broad scale inferences regarding response to change (Snelgrove et al., 2014).

Fertilisers have commonly been used to test the effects of increased nutrient loading on marine soft sediment habitats, but methodological development has been haphazard making cross-study comparisons near impossible. We extended the review of Worm et al. (2000) to include the recent literature, and found 47 enrichment studies conducted in intertidal and subtidal habitats (Appendix 1). Approximately half of the studies tested nutrient limitation and growth in macrophytes (mainly seagrasses), and half examined nutrient enrichment effects on benthic communities and food webs. Slow release fertilisers, such as Osmocote ${ }^{\circledR}$, were used in 33 of 47 (70\%) studies, but these fertilisers varied considerably in their elemental makeup. Similarly, studies had a very wide range of application rates (between 3 and $750 \mathrm{~g} \mathrm{~N} \mathrm{~m}^{-2}$ (Fig. 1)); while some were based on previously published experiments or site-specific pilot studies ( 25 of 47 ), in $>50 \%$ of studies application rates were not justified ( 27 of 47). Applications of fertiliser to surficial sediments were common; in $53 \%$ of studies additions were $<5 \mathrm{~cm}$ deep, and in many studies (36\%) only the top $1 \mathrm{~cm}$ of sediment received fertiliser. Moreover, in only 20 of 47 studies were enrichment levels (i.e. realised treatment effect) on sediment nutrient pore water concentrations reported. Relative increases in pore water nitrogen concentrations in these 20 studies ranged from 7 to 352 times ambient levels (Fig. 1) but enrichment level comparisons are difficult to make because the depth of sampling $(0-20 \mathrm{~cm})$ was not standardised. These inconsistencies and methodological limitations indicate a need for a more 


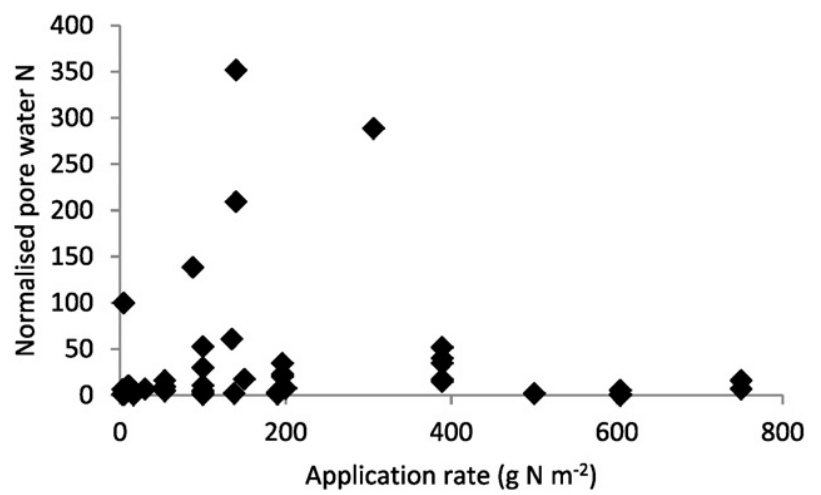

Fig. 1. Normalised (relative to ambient) pore water nitrogen concentration as a function of fertiliser application rate in the 20 studies for which such data were reported (Appendix 1).

informed approach to enrichment experiments that justifies fertiliser application rates, and improves understanding of the factors that may influence the resulting pore water nutrient concentrations.

Firstly, when planning manipulative field or mesocosm experiments it is useful to consider potential enrichment levels for a given application rate to avoid unrealistically high or undetectable pore water nutrient concentrations. Secondly, Worm et al. (2000) showed that enrichment level (i.e. pore water nutrient increase) could not be predicted by the initial fertiliser application rate, time since application and application depth using multiple linear regression analysis of literature studies (overall $\mathrm{r}^{2}=0.07, \mathrm{p}=0.53, \mathrm{n}=34$ ). We repeated this analysis on the larger set of literature and revealed a similar result $\left(r^{2}=0.01, p=0.92, n=48\right)$. The implication is that local environmental variables and variability in methods may strongly affect the enrichment level. We also note that previous studies have frequently overlooked co-variables or failed to assess their influence on the nutrient treatment.

Marine soft sediment ecosystems vary greatly in their physical and biological makeup, and consequently their biogeochemical processes (Braeckman et al., 2014). For example, sediment properties are important to consider in studies of benthic nutrient cycling since these influence diffusion and solute transport (e.g. Blackburn and Henriksen, 1983; Glud, 2008; Hohaia et al., 2013; Huettel et al., 2003), as well as macrofauna behaviour and ecosystem functioning (e.g. Lohrer et al., 2004; Pratt et al., 2013; Woodin et al., 2012). Benthic macrofauna are known to influence nitrogen cycling (Aller, 1988; Kristensen et al., 1991; Laverock et al., 2011), and the presence of macrophytes and microphytobenthos is also expected to influence pore water nutrient concentrations and the level of experimental enrichment. The majority of enrichment experiments have been conducted in vegetated sediments (28 of 47) and only 10 of the 19 studies conducted in unvegetated sediments reported significant increases in pore water concentrations (Appendix 1). Our literature review shows that there is insufficient information for researchers designing enrichment experiments in un-vegetated sediments, and that there is a need to experimentally assess the role of habitat and biological processes in ameliorating pore water nutrient concentrations.

Our study develops protocols that are simple and cost-effective for in situ nitrogen enrichment experiments. The method was developed based on the published literature and a recent intertidal sandflat experiment that encompassed a wide range of sediment types, macrophyte coverage, and variations in benthic macrofauna community composition (Table 1). Our study design allowed us to document the degree to which surface and sub-surface sediment pore water nitrogen concentrations were elevated as a function of fertiliser application rate and time since application, in relation to environmental variables to serve as a guide for future studies.
Table 1

Sediment properties and macrofauna variables as a function of fertiliser application rate Values are medians with minimum and maximum in parentheses $(\mathrm{n}=28)$.

\begin{tabular}{|c|c|c|c|}
\hline Variable & $\begin{array}{l}\text { Control } \\
\left(0 \mathrm{~g} \mathrm{~N} \mathrm{~m}^{-2}\right)\end{array}$ & $\begin{array}{l}\text { Medium } \\
\left(150 \mathrm{~g} \mathrm{~N} \mathrm{~m}^{-2}\right)\end{array}$ & $\begin{array}{l}\text { High } \\
\left(600 \mathrm{~g} \mathrm{~N} \mathrm{~m}^{-2}\right)\end{array}$ \\
\hline \multicolumn{4}{|l|}{ Sediment properties } \\
\hline Seagrass (\% cover) & $16(0-84)$ & $20(0-97)$ & $21(0-75)$ \\
\hline OC (\%) & $0.9(0.6-2.0)$ & $0.9(0.6-2.0)$ & $1.0(0.6-1.8)$ \\
\hline Mud $(\%<63 \mu \mathrm{m})$ & $1.78(0-15)$ & $0.62(0-14)$ & $0.42(0-12)$ \\
\hline $\mathrm{GSM}(\mu \mathrm{m})$ & $215(177-241)$ & $220(182-242)$ & $219(190-250)$ \\
\hline Chl- $a$ ( $\mu \mathrm{g} \mathrm{g}^{-1}$ sediment $)$ & $9.3(3-23)$ & $10.0(5-32)$ & $9.5(5-28)$ \\
\hline \multicolumn{4}{|l|}{ Macrofauna } \\
\hline$S\left(\right.$ taxa core $\left.^{-1}\right)$ & $26(11-38)$ & $23(7-40)$ & $26(11-45)$ \\
\hline $\mathrm{N}\left(\right.$ n core $\left.^{-1}\right)$ & $107(19-419)$ & $58(8-345)$ & $62(22-574)$ \\
\hline $\mathrm{H}^{\prime}$ & $2.4(1.1-3.1)$ & $2.4(1.6-3.0)$ & $2.4(1.1-3.0)$ \\
\hline
\end{tabular}

$\mathrm{OC}=$ sediment organic content, Mud = sediment mud content, $\mathrm{GSM}=$ grain size median, Chl- $a=$ chlorophyll $a$ content, $\mathrm{S}=$ number of species, $\mathrm{N}=$ number of individuals, $\mathrm{H}^{\prime}=$ Shannon diversity.

\section{Methods}

\subsection{Experiment setup}

A large scale nitrogen enrichment experiment was set up on a $300,000 \mathrm{~m}^{2}$ area of intertidal sand flat on the Tapora Bank in the Kaipara Harbour, northern New Zealand ( $\left.36^{\circ} 39^{\prime} \mathrm{S}, 174^{\circ} 29^{\prime} \mathrm{E}\right)$. The study area is composed mostly of permeable sediments of varying mud (particle size $<63 \mu \mathrm{m}$ ) content (Table 1), and is subject to tidal flushing, wind waves, and run off from a mostly agricultural catchment. Treatment plots $(1 \mathrm{~m} \times 1 \mathrm{~m})$ consisting of control (no addition), medium (150 $\mathrm{g} \mathrm{N} \mathrm{m}^{-2}$ ) and high (600 $\mathrm{g} \mathrm{N} \mathrm{m}^{-2}$ ) nitrogen enrichment were established at 28 sites (each in a $5 \times 5 \mathrm{~m}$ area) across the study area. These application rates were based on the median and upper quartile values from the literature review (Appendix 1). We used Nutricote ${ }^{\circledR}$ $\mathrm{N}$ (70 d, 40-0-0 N:P:K), a controlled release coated urea fertiliser containing no phosphorus, potassium or trace elements. A nitrogen-only fertiliser was used since it is typically the limiting nutrient in these systems, and urea quickly hydrolyses to ammonium $\left(\mathrm{NH}_{4}^{+}\right)$(Lomstein et al., 1989), the most common form of nitrogen in New Zealand estuaries (Tay et al., 2013).

Fertiliser was applied to each plot in a series of 20 evenly spaced $3 \mathrm{~cm}$ diameter $15 \mathrm{~cm}$ deep holes made in the sediment using a hand held corer. Each hole received an equal volume of fertiliser and the intact sediment core plugs were replaced immediately to minimise disturbance to the sediment. For less cohesive sediments, an outer core sleeve was used to prevent holes from infilling while fertiliser was added. Control plots were similarly cored and received an equal volume (as the high treatment) of pea gravel of similar diameter to the fertiliser pellets. With this method we were able to establish $841 \mathrm{~m}^{2}$ experimental plots across a $300,000 \mathrm{~m}^{2}$ study site in one low tide $(4-5 \mathrm{~h})$ with a team of six people. In a preliminary study, this technique provided even elevation of pore water $\mathrm{NH}_{4}^{+}$throughout a $1 \mathrm{~m}^{2}$ plot (1.3-2.0 fold variation in concentration between the plot centre, edge and halfway in between) when sampled four weeks after application, with enrichment effects undetectable $0.5 \mathrm{~m}$ beyond the plot boundary.

\subsection{Sampling}

Samples were collected four weeks (pore water and sediment properties) and seven weeks after the fertiliser addition (pore water, sediment properties, macrofauna). Sampling times were chosen to allow enough time for the system to respond (based on our literature review and pilot study), and were within the $70 \mathrm{~d}$ release period of the fertiliser. Replicate, randomly placed sediment cores ( $2.6 \mathrm{~cm}$ dia.) from each plot were pooled and homogenised for analysis of sediment properties $(\mathrm{n}=$ $5,0-2 \mathrm{~cm}$ depth) and pore water nutrients ( $\mathrm{n}=4,0-2 \mathrm{~cm}$ and $5-7 \mathrm{~cm}$ depths, separated). Sediment samples were kept in the dark and 
transported on ice to the laboratory. At the end of the experiment, two cores (13 cm dia., $15 \mathrm{~cm}$ depth) were collected near the centre of each plot for analysis of the benthic macrofaunal community. Cores were sieved on a $500 \mu \mathrm{m}$ mesh, preserved in 50\% isopropyl alcohol, and stained with Rose Bengal. All organisms were counted and identified to the lowest possible taxonomic level (usually species).

In the laboratory, pore water was extracted immediately by centrifuge and filtered ( $1.1 \mu \mathrm{m}$, Whatman GC glass fibre filters) prior to freezing $\left(-20^{\circ} \mathrm{C}\right)$ (Lohrer et al., 2010). Pore water samples were later analysed for $\mathrm{NH}_{4}^{+}$using a Lachat QuickChem 8000 Series FIA + (Zellweger Analytics Inc. Milwaukee, Wisconsin, 53218, USA) using standard operating procedures for flow injection analysis. Sediment samples were frozen at $-20{ }^{\circ} \mathrm{C}$ until analysis. Particle grain size was measured after removal of organic matter with $10 \%$ hydrogen peroxide, using a Malvern Mastersizer 2000 (particle size range 0.05-2000 $\mu \mathrm{m}$ ) (Singer et al., 1988). Sediment organic matter content was determined by weight loss on ignition of dry sediments $\left(550{ }^{\circ} \mathrm{C}\right.$ for $4 \mathrm{~h}$ ) according to Parker (1983). Chlorophyll $a$ (Chl a) was extracted from freezedried sediment in $90 \%$ acetone, then fluorescence of samples was measured using a Turner Designs 10-AU flourometer (Arar and Collins, 1997). Prior to sampling, photographs of $0.25 \mathrm{~m}^{2}$ in the centre of each plot were taken and a random point count method used to estimate seagrass (Zostera muelleri Irmisch ex Asch.) coverage (\%) (see Kohler and Gill, 2006).

Summary statistics and univariate tests were carried out using STATISTICA version 11 (StatSoft Inc., 2012) after first identifying and removing outliers ( $\mathrm{n}<5$ per treatment). Paired $t$-tests were used to test for differences in pore water $\mathrm{NH}_{4}^{+}$concentration between depth strata four and seven weeks after enrichment. Multivariate analyses were conducted using PRIMER 7.0 PERMANOVA + (Clarke and Gorley, 2015). A Euclidean distance matrix was generated using $\log (\mathrm{x}+1)$ transformed pore water concentrations from both depth strata. This matrix was then used to run a repeated measures permutational multivariate analysis of variance (PERMANOVA) to test the effects of application rate (fixed factor, 3 levels), sample time (fixed factor, 2 levels) and their interaction on multivariate pore water $\mathrm{NH}_{4}^{+}$concentration, plot was treated as a random factor (84 levels) nested within treatment. Post-hoc PERMANOVA pairwise $t$-tests were used to identify where significant treatment and time effects occurred.

To investigate whether measured environmental variables (Table 1) could explain variations in pore water $\mathrm{NH}_{4}^{+}$concentration, a separate Euclidean distance matrix of raw pore water concentration data (using both depth strata) from week seven was generated for each treatment. Distance-based linear models (DistLM) were run on the matrices to determine which variables were correlated with pore water $\mathrm{NH}_{4}^{+}$concentrations (e.g. as in Pratt et al. (2015)). This multiple regression analysis uses permutation and does not assume normality, so data were left untransformed because we wanted to retain heterogeneity (and transformations did not change results). Predictor variables were however standardised (between 0 and 1 ) to account for differences in the magnitude and range of units. Marginal tests were used to identify individually significant correlations with pore water concentration, followed by a backwards elimination procedure, using the corrected Akaike information criterion (AICc) to select the best individual or combination of variables. AICc was the most the appropriate selection criterion since the sample size was small relative to the number of variables (Burnham and Anderson, 2002).

\section{Results}

Our technique successfully elevated pore water $\mathrm{NH}_{4}^{+}$concentrations for the duration of the seven week experiment, with the depthaveraged medium and high treatments respectively 1-110 and 4-580 times greater than ambient conditions (Fig. 2). These ranges are near to (medium treatment) or greater than (high treatment) the range of values from reviewed studies using application rates between 3 and $750 \mathrm{~g} \mathrm{~N} \mathrm{~m}^{-2}$ (Fig. 1).

Despite high within treatment variability, there was a highly significant effect of fertiliser application rate on pore water $\mathrm{NH}_{4}^{+}$concentration (depth strata combined), and post-hoc tests revealed significant differences between all treatment levels (Table 2). There was also a weakly significant effect of sample date, with pore water $\mathrm{NH}_{4}^{+}$concentrations higher in week seven than week four, although plots within specific treatments did not all respond temporally in the same way (i.e. the significant plot nested in treatment effect). The lack of a significant treatment $\times$ time interaction indicates that the temporal increase in pore water $\mathrm{NH}_{4}^{+}$concentrations was a general site phenomenon, and not related solely to changes in release rate in fertilised plots. Four and seven weeks after enrichment, both fertiliser treatments showed higher pore water $\mathrm{NH}_{4}^{+}$concentrations in deeper sediments $(5-7 \mathrm{~cm})$ than surface sediments $(0-2 \mathrm{~cm})$ (paired $t$-tests $\mathrm{p}<0.01$ ). Ambient (control plot) $\mathrm{NH}_{4}^{+}$concentrations were also higher in deeper than shallower sediments although the differences were not as pronounced (paired $t$ tests $\mathrm{p}<0.06$; Fig. 2 ).

Sediment properties and indicators of macrofaunal community structure varied widely across the experimental area (Table 1 ), but none of these variables were significantly correlated with pore water $\mathrm{NH}_{4}^{+}$concentration in the control and medium addition plots (Table 3 ). However, in the high addition treatment pore water $\mathrm{NH}_{4}^{+}$ concentration was negatively correlated with distance from shore, organic and mud content, seagrass coverage, and benthic macrofauna diversity (Table 3 ). Sediment $\mathrm{Chl} a$ content was the only variable positively correlated with pore water $\mathrm{NH}_{4}^{+}$concentration. The most parsimonious model of pore water concentration in the high treatment included Chl $a$ and number of macrofauna taxa, which collectively explained $42 \%$ of the total variation.

\section{Discussion}

In order to conduct experiments that simulate realistic eutrophic sedimentary conditions, an adequate nutrient application technique is required together with a benchmarked application rate to achieve the desired level of enrichment. Since the Worm et al. (2000) review 15 years ago there has not been sufficient improvement in methodology available in the literature to help plan enrichment experiments. We developed a technique to enrich intertidal sediments in one application, without disturbing the entire sediment profile, which can supply nutrients for at least seven weeks. This technique provides an even spread of nutrient concentrations throughout a $1 \times 1 \mathrm{~m}^{2}$ plot minimising nutrient gradients. Our method is simple and cheap, can be used for both long and short-term enrichment experiments, and allows high levels of replication. Fertiliser pellets appeared intact after 7 weeks, and we expect that enrichment would have continued for at least $70 \mathrm{~d}$ (manufacturers estimated release period). Longer term experiments could consider using fertilisers with slower release rates to avoid repeat applications (e.g. Nutricote ${ }^{\circledR} \mathrm{N} 140 \mathrm{~d}$ ). It proved easy to use in a range of intertidal sediment types and could also be applied in other aquatic soft sediment environments, including sub-tidal and lake sediments with the use of SCUBA. Subtidal applications would be made easier with the use of fertiliser packets such as mesh bags, however biodegradable materials are recommended to avoid retrieval. The use of a duel core (i.e. an inner and outer core sleeve) may be required to prevent holes infilling and to ensure fertiliser is buried to the required depth. We recommend for all aquatic deployments workers verify that their chosen fertiliser is negatively buoyant and bury it to a depth beyond the expected mobile sediment layer.

Fertiliser type, application rate, and depth need to be carefully considered in terms of the study aims, duration, and receiving environment. We observed high variability in the enrichment level and despite measuring a large number of site specific environmental variables, much of this could not be explained. Our enrichment levels tended to be higher 


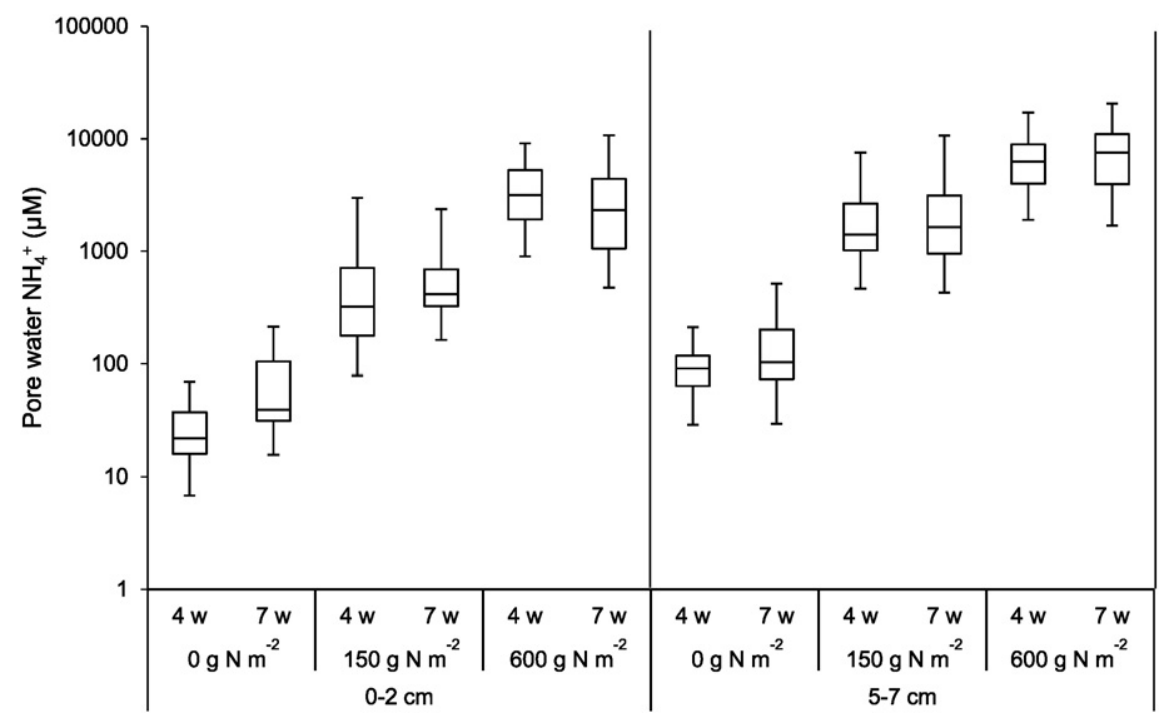

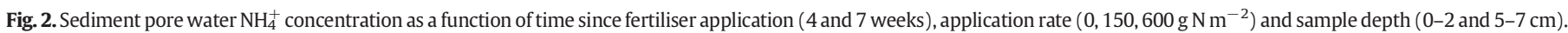
Boxes represent $25 \%$, median and $75 \%$ distributions, with whiskers the non-outlier minimum and maximum $(\mathrm{n}=28)$. Note $\log _{10}$ scale of $\mathrm{y}$-axis.

than those measured in other studies, which could be due to shallow enrichment techniques and/or differences in pore water sampling and monitoring used in other studies (Appendix 1). Worm et al. (2000) emphasised the importance of careful pore water sampling during experiments to be sure of a consistent and quantifiable enrichment level. A standardised sampling technique is also required since concentrations of nitrogen species typically change throughout the sediment profile (Vanderborght and Billen, 1975; Zhang et al., 2013). Depending on the depth sampled, the values obtained could be very different to the desired level; in our study enrichment levels were greater in deeper than in surface sediments (Fig. 2). Sampling the surface sediments may mean the measured enrichment is very low or undetectable, and sampling too deep may render values that are unrepresentative of the active benthos layer. Therefore, we recommend targeting a specific sediment profile area of importance to the study, and/or pooling across sediment depths which integrates the variability in enrichment level throughout the sediment profile, reduces the amount of samples to analyse, and gives more general, comparable values.

Our literature review showed that many studies (53\%) applied fertiliser to surface sediments ( $\leq 5 \mathrm{~cm}$ depth), mimicking eutrophication effects from the water column, but not the long term impacts of eutrophication on sediment pore water. Surface sediments are more likely to be influenced by water column hydrodynamics and pore water advection processes (review by Santos et al., 2012) which may speed up nutrient release from the fertiliser. Our method enriched the sediment profile at least from 0 to $7 \mathrm{~cm}$ depth, and is likely to elevate $\mathrm{NH}_{4}^{+}$availability at the sediment water interface. This zone includes the rhizosphere of seagrasses, and the layer of most macrofaunal activity in marine soft sediment habitats (Gilbert et al., 1998; Teal et al., 2008).

Table 2

Results of a repeated measures PERMANOVA comparing pore water $\mathrm{NH}_{4}^{+}$concentration as a function of fertiliser application rate (treatment) and sample date (time). The PERMANOVA was based on Euclidean distance of $\log _{10}(x+1)$ pore water concentrations at $0-2$ and $5-7 \mathrm{~cm}$ depth. Post-hoc pair-wise tests are given for significant treatment effects.

\begin{tabular}{lrcccll}
\hline Source & df & SS & MS & Pseudo-F & Perm-p & Post-hoc \\
\hline Treatment & 2 & 1006 & 503 & 162 & 0.001 & $\mathrm{C}<\mathrm{M}<\mathrm{H}$ \\
Time & 1 & 9.68 & 9.68 & 4.82 & 0.021 & $4 \mathrm{w}<7 \mathrm{w}$ \\
Plot (Treatment) & 81 & 250 & 3.09 & 1.54 & 0.012 & \\
Treatment $\times$ Time & 2 & 3.02 & 1.51 & 0.75 & 0.547 & \\
Residual & 81 & 162 & 2.01 & & & \\
\hline
\end{tabular}

Treatments: $\mathrm{C}=0, \mathrm{M}=150, \mathrm{H}=600 \mathrm{~g} \mathrm{~N} \mathrm{~m}^{-2}$.

Time: $4 \mathrm{w}=4$ weeks, $7 \mathrm{w}=7$ weeks.
The elevated pore water concentrations that our method delivered are equivalent to the concentrations that are measured in enriched estuaries globally (Appendix 2), simulating the long term effects of eutrophication. Unlike our method, in situ water column or surface sediment enrichment methods cannot produce this effect due to dilution and high variability in sediment-water coupling.

Many physical and biological factors influence the level of nutrient enrichment, as well as the type and severity of consequences to an ecosystem's functioning. Nutrient cycling and efflux from the sediments are influenced by the sedimentary environment (Blackburn and Henriksen, 1983; Glud, 2008; Santos et al., 2012), benthic macrofauna (Bertics et al., 2010; Laverock et al., 2011), and macrophyte communities (Kenworthy et al., 1982). Our results show that primary consideration should be given to benthic macrofauna and sediment properties when estimating potential enrichment levels of experiments. In heterogeneous environments, researchers should consider the interactions and variability of site environmental and biological variables and their influence on enrichment levels. This is particularly important for studies of biological community response to enrichment. If researchers wish to achieve a specific level of enrichment, especially for studies encompassing environmental variability, a pilot study is recommended so that application rates can be tailored to achieve the desired pore water concentrations and reduce variability.

Table 3

Significant predictors (marginal test results $\mathrm{p}<0.1$ ) of pore water $\mathrm{NH}_{4}^{+}$concentration as a function of fertiliser application rate after seven weeks. Prop. is the proportion of variation explained and direction of correlation is given in parentheses. Variables in bold were those included in the best DistLM model of pore water concentration, and full model indicates the proportion of explained variance attributed to each. Variable abbreviations are given in Table 1.

\begin{tabular}{|c|c|c|c|c|}
\hline Treatment & Variable & Pseudo-F & Prop. & Full mode \\
\hline $0 \mathrm{~g} \mathrm{~N} \mathrm{~m}^{-2}$ & \multicolumn{4}{|c|}{ No individually significant predictors } \\
\hline $150 \mathrm{~g} \mathrm{~N} \mathrm{~m}^{-2}$ & \multicolumn{4}{|c|}{ No individually significant predictors } \\
\hline \multirow[t]{8}{*}{$600 \mathrm{~g} \mathrm{~N} \mathrm{~m}^{-2}$} & Distance to shore & 5.42 & $0.20^{* *}(-)$ & \\
\hline & $\mathrm{OC}$ & 4.76 & $0.18^{* *}(-)$ & \\
\hline & Mud & 2.99 & $0.12^{*}(-)$ & \\
\hline & Chl a & 2.94 & $0.12 *(+)$ & \multirow[t]{2}{*}{$16 \%$} \\
\hline & Seagrass & 5.70 & $0.21^{* * * *}(-)$ & \\
\hline & $\mathbf{S}$ & 7.84 & $0.26^{* * *}(-)$ & \multirow[t]{2}{*}{$30 \%$} \\
\hline & $\mathrm{H}^{\prime}$ & 7.93 & $0.26^{* * *}(-)$ & \\
\hline & & & Total & $42 \%$ \\
\hline
\end{tabular}

\footnotetext{
${ }^{*} \mathrm{p} \leq 0.1$.

** $\mathrm{p} \leq 0.05$.

*** $\mathrm{p} \leq 0.01$.
} 
In order to meaningfully progress eutrophication and nutrient cycling research, more in situ experimentation is needed. An important outcome of this work is that the same application rate can achieve very different enrichment levels even within a single habitat; we measured high variability in enrichment level across a sandflat at a scale $<1 \mathrm{~km}$. This scale of variability reflects real-world complexity and should be incorporated into future experiments in order to increase generality and application of conclusions. The way to achieve this is through well replicated gradient designs that consider co-variables (Eberhardt and Thomas, 1991; Ellis and Schneider, 2008; Hewitt et al., 2007; Thrush et al., 1997). Many of the reviewed nutrient enrichment studies had research questions that required categorical type designs; the majority (68\%) used only a single fertiliser application rate, the average number of treatment replicates was just five, and more than half the studies (57\%) were conducted across spatial scales much less than $1 \mathrm{~km}$ (Appendix 1). Although these past studies represent an invaluable body of work, it would be complemented by experiments conducted across environmental gradients and larger spatial scales. Combining in situ assay techniques (such as sediment nutrient enrichment), with novel interaction network approaches to data analysis will provide valuable ecological tools for studies of multiple stressor effects, ecosystem resilience, and tipping points in real world settings (Thrush et al., 2014). Using previously employed methods this seems unachievable and expensive in time and money. We have shown that such experiments can be conducted relatively easily with a simple technique that:

1. can be used for a highly replicated experiment across a large area,

2. delivers nutrient enrichment for at least seven weeks that scales with application rate,
3. requires only one initial set up,

4. has no need to build or install special diffusion devices, and

5. is inexpensive in time and money.

\section{Author contribution statement}

Substantial contributions towards this paper were made by all the authors. SFT, CAP, CK and EJD designed the study. The acquisition of data through field and laboratory work was done by LVH, EJD, CAP and CK. EJD and CAP analysed and interpreted the data. The manuscript was written by EJD with input from CAP, CK and SFT. All authors have approved this final version.

\section{Acknowledgements}

We thank all those involved in field sampling and laboratory work especially Drew Lohrer, Barry Greenfield, Sarah Hailes, Lisa McCartain, Katie Cartner, Carsten Dormann, and Rebecca Gladstone-Gallagher. This work was funded by the Marsden Fund, Royal Society of New Zealand (NIW1102) to SFT and a Marie-Curie International Outgoing Fellowship (FP7-PEOPLE-2011-IOF) to CK. EJD was funded by a University of Waikato Doctoral Scholarship. These funders had no role in the study design, interpretation, or writing of this manuscript. EJD and CAP gratefully acknowledge the Walter and Andree de Nottbeck Foundation, A Norkko and staff at Tvärminne Zoological Station, University of Helsinki for support during manuscript preparation. We thank one anonymous reviewer for their constructive comments that have improved the paper.

\section{Appendix A}

Appendix 1

Summary of published literature of in situ sediment fertiliser enrichment studies.

\begin{tabular}{|c|c|c|c|c|c|c|c|c|c|c|c|}
\hline \multirow[b]{2}{*}{ Source } & \multicolumn{5}{|c|}{ Experimental design } & \multicolumn{4}{|c|}{ Fertiliser application } & \multicolumn{2}{|c|}{ Pore water enrichment } \\
\hline & $\begin{array}{l}\text { Purpose of } \\
\text { study }\end{array}$ & Substrate & Sites & $\begin{array}{l}\text { Treatment } \\
\text { replicates }\end{array}$ & $\begin{array}{l}\text { Spatial scale } \\
(\mathrm{km})\end{array}$ & Type & $\begin{array}{l}\text { Diffuser } \\
\text { device }\end{array}$ & $\begin{array}{l}\text { Depth } \\
(\mathrm{cm})\end{array}$ & $\begin{array}{l}\text { Rate }(\mathrm{g} \mathrm{N} \\
\left.\mathrm{m}^{-2}\right)\end{array}$ & $\begin{array}{l}\text { Effect } \\
\text { detected }\end{array}$ & $\begin{array}{l}\text { Effect } \\
\text { size }\end{array}$ \\
\hline Orth (1977) & SG & Veg & 2 & 40 & $>5$ & SR & $\mathrm{N}$ & $0-1$ & $64-128$ & NR & - \\
\hline $\begin{array}{l}\text { Bulthuis and Woelkerling } \\
\text { (1981) }\end{array}$ & SG & Veg & 1 & 3 & $<1$ & Inorg & $\mathrm{Y}$ & 10 & 100 & $\uparrow$ & $4.8-30$ \\
\hline Pulich Jr. (1985) & SG & Veg & 2 & 12 & $>5$ & SR & $\mathrm{N}$ & $0-1$ & 20 & NR & - \\
\hline Dennison et al. (1987) & SG & Veg & 2 & 12 & $<1$ & Inorg & $\mathrm{Y}$ & $0-10$ & NR & $\uparrow$ & - \\
\hline Williams (1987) & SG & Veg & 1 & 8 & $<1$ & SR & $\mathrm{Y}$ & $0-5$ & 140 & $\uparrow$ & $209-352$ \\
\hline Powell et al. (1989) & SG & Veg & 5 & 5 & $<1$ & Org & $\mathrm{N}$ & 0 & NR & $\uparrow$ & - \\
\hline Short et al. (1990) & SG & Veg & 1 & 6 & $<1$ & SR & $\mathrm{N}$ & $20-25$ & NR & NR & - \\
\hline Williams (1990) & SG & Veg & 1 & 4 & $<1$ & SR & $\mathrm{Y}$ & $0-5$ & 604 & $\uparrow$ & $0.19-5.6$ \\
\hline Perez et al. (1991) & SG & Veg & 1 & 1 & $<1$ & SR & $\mathrm{N}$ & $0-1$ & 2150 & NR & - \\
\hline Bulthuis et al. (1992) & SG & Veg & 5 & 15 & $>5$ & SR & $\mathrm{Y}$ & 10 & 100 & $\uparrow$ & $1.0-52.6$ \\
\hline $\begin{array}{l}\text { Flothmann and Werner } \\
\text { (1992) }\end{array}$ & $\mathrm{EU}$ & Un-veg & 1 & 6 & $<1$ & Inorg & $\mathrm{Y}$ & 8 & NR & $\uparrow$ & - \\
\hline $\begin{array}{l}\text { Kenworthy and Fonseca } \\
\text { (1992) }\end{array}$ & SG & Veg & 3 & 9 & $1-5$ & SR & $\mathrm{Y}$ & $?$ & $3.2-53$ & NR & - \\
\hline Murray et al. (1992) & SG & Veg & 1 & $?$ & $<1$ & Inorg & $\mathrm{Y}$ & 15 & $100-200$ & $\uparrow$ & $1.3-2.0$ \\
\hline $\begin{array}{l}\text { Williams and Ruckelshaus } \\
\text { (1993) }\end{array}$ & SG & Veg & 1 & 7 & $<1$ & Inorg & $\mathrm{Y}$ & $0-5$ & 54 & $\uparrow$ & $5.0-9.3$ \\
\hline Erftemeijer et al. (1994) & SG & Veg & 3 & 18 & $>5$ & SR & $\mathrm{N}$ & $10-15$ & 4.9 & $\uparrow$ & 1.2 \\
\hline Fonseca et al. (1994) & SG & Veg & 2 & 2 & $>5$ & SR & $\mathrm{Y}$ & 7.6 & 694 & NR & - \\
\hline Feller (1995) & M & Veg & 1 & 3 & $<1$ & SR & $\mathrm{Y}$ & $0-10$ & $30-135$ & $\uparrow$ & $6.8-61.0$ \\
\hline McGlathery (1995) & SG & Veg & 2 & 2 & $1-5$ & SR & $\mathrm{Y}$ & $?$ & NR & $?$ & - \\
\hline Pedersen (1995) & $A+S G$ & Veg & 1 & 1 & $<1$ & Inorg & $\mathrm{N}$ & $?$ & NR & NR & - \\
\hline Posey et al. (1995) & $\mathrm{EU}+\mathrm{FW}$ & Un-veg & 1 & 15 & $<1$ & SR/Inorg & $\mathrm{Y}$ & $0,0-7.5$ & 2.3 & NR & - \\
\hline van Lent et al. (1995) & SG & Veg & 2 & 8 & $>5$ & SR & $\mathrm{N}$ & 10 & 190 & $\uparrow$ & $1.4-3.0$ \\
\hline Vetter (1996) & EU & Un-veg & 1 & 4 & $<1$ & Org & $\mathrm{N}$ & 0 & NR & $?$ & - \\
\hline $\begin{array}{l}\text { Ceccherelli and Cinelli } \\
\text { (1997) }\end{array}$ & $\mathrm{EU}+\mathrm{A}+\mathrm{SG}$ & Veg & 1 & 6 & $<1$ & SR & $\mathrm{Y}$ & $1-6$ & 10.4 & NS & 10.5 \\
\hline Udy and Dennison (1997) & SG & Veg & 1 & 3 & $<1$ & SR & $\mathrm{N}$ & $0.5-1.0$ & 88 & $\uparrow$ & 139 \\
\hline Posey et al. (1999) & $\mathrm{EU}$ & Un-veg & 2 & 14 & $>5$ & SR & $\mathrm{Y}$ & $0-7.5$ & 69 & NR & - \\
\hline Piceno and Lovell (2000) & EU, B & Veg & 1 & 1 & $<1$ & Inorg & $\mathrm{N}$ & 0 & 16.3 & NS & $0.74-1.44$ \\
\hline Worm et al. (2000) & $\begin{array}{l}\text { Method } \\
\text { review }\end{array}$ & Un-veg & 1 & 8 & $<1$ & SR & $\mathrm{N}$ & $0-10$ & 150 & $\uparrow$ & 17.5 \\
\hline
\end{tabular}


Appendix 1 (continued)

\begin{tabular}{|c|c|c|c|c|c|c|c|c|c|c|c|}
\hline \multirow[b]{2}{*}{ Source } & \multicolumn{5}{|c|}{ Experimental design } & \multicolumn{4}{|c|}{ Fertiliser application } & \multicolumn{2}{|c|}{ Pore water enrichment } \\
\hline & $\begin{array}{l}\text { Purpose of } \\
\text { study }\end{array}$ & Substrate & Sites & $\begin{array}{l}\text { Treatment } \\
\text { replicates }\end{array}$ & $\begin{array}{l}\text { Spatial scale } \\
(\mathrm{km})\end{array}$ & Type & $\begin{array}{l}\text { Diffuser } \\
\text { device }\end{array}$ & $\begin{array}{l}\text { Depth } \\
(\mathrm{cm})\end{array}$ & $\begin{array}{l}\text { Rate }(\mathrm{g} \mathrm{N} \\
\left.\mathrm{m}^{-2}\right)\end{array}$ & $\begin{array}{l}\text { Effect } \\
\text { detected }\end{array}$ & $\begin{array}{l}\text { Effect } \\
\text { size }\end{array}$ \\
\hline Posey et al. (2002) & EU, FW & Un-veg & 2 & 14 & $>5$ & SR & Y & $0-7.5$ & NR & $\uparrow$ & - \\
\hline $\begin{array}{l}\text { Morris and Keough } \\
\text { (2003b) }\end{array}$ & $\mathrm{EU}$ & Un-veg & 1 & 8 & $<1$ & SR & $\mathrm{Y}$ & $0-1$ & $1579-3158$ & NS & - \\
\hline $\begin{array}{l}\text { Morris and Keough } \\
\text { (2003a) }\end{array}$ & $\mathrm{EU}$ & Un-veg & 2 & 12 & $>5$ & SR & $\mathrm{Y}$ & $1-2$ & $123-2467$ & $\uparrow$ & - \\
\hline $\begin{array}{l}\text { Ferdie and Fourqurean } \\
\text { (2004) }\end{array}$ & SG & Veg & 6 & 24 & $>5$ & SR & $\mathrm{N}$ & 0 & NR & NR & - \\
\hline Armitage et al. (2005) & SG, FW & Veg & 6 & 36 & $>5$ & SR & $\mathrm{N}$ & 0 & NR & NR & - \\
\hline Lever and Valiela (2005) & $\mathrm{EU}$ & Un-veg & 3 & 15 & $1-5$ & SR & $\mathrm{Y}$ & 1 & 196 & $\uparrow$ & $20.4-34.6$ \\
\hline Armitage et al. (2006) & EU & Veg & 4 & 24 & $>5$ & SR & $\mathrm{N}$ & 0 & NR & NR & - \\
\hline Gil et al. (2006) & $\mathrm{EU}$ & Veg & 2 & 12 & $>5$ & SR & $\mathrm{N}$ & $0-1$ & NR & NR & - \\
\hline Posey et al. (2006) & EU, FW & Un-veg & 4 & 36 & $>5$ & SR & $\mathrm{Y}$ & $0-7.5$ & NR & NR & 2.2 \\
\hline Stutes et al. (2006) & EU & Un-veg & 2 & 20 & $1-5$ & $\mathrm{QR}$ & Y & 10 & $3.2-4.5$ & $\uparrow$ & $1.3-100$ \\
\hline O'Brien et al. (2009) & $\mathrm{EU}$ & Un-veg & 1 & 24 & $<1$ & SR & $\mathrm{N}$ & 4 & 389 & $\uparrow$ & $14.9-51.9$ \\
\hline Santos et al. (2009) & EU & Un-veg & 1 & 6 & $<1$ & $\mathrm{QR}$ & $\mathrm{N}$ & 0 & NR & NS & - \\
\hline O'Brien et al. (2010) & $\mathrm{EU}$ & $\begin{array}{l}\text { Veg }+ \\
\text { Un-veg }\end{array}$ & 1 & 5 & $>5$ & SR & $\mathrm{N}$ & 5 & 750 & $\uparrow$ & $7.0-16.0$ \\
\hline Olsen and Valiela (2010) & SG & Veg & 1 & 6 & $<1$ & SR & $\mathrm{N}$ & $0-20$ & 306 & $\uparrow$ & 289 \\
\hline Piehler et al. (2010) & $\mathrm{EU}$ & Un-veg & 1 & 4 & $<1$ & Inorg & $\mathrm{N}$ & 0 & NR & NS & - \\
\hline Cebrian et al. (2012) & $\mathrm{EU}$ & Un-veg & 2 & 20 & $1-5$ & $\mathrm{QR}$ & $\mathrm{Y}$ & 10 & NR & $\uparrow$ & - \\
\hline Fitch and Crowe (2012) & EU & Un-veg & 1 & 8 & $<1$ & SR & Y & $0-6$ & $10-20$ & $\uparrow$ & $4.8-7.6$ \\
\hline O'Gorman et al. (2012) & EU & Un-veg & 1 & 8 & $<1$ & SR & Y & $0-6$ & $10-20$ & NR & - \\
\hline $\begin{array}{l}\text { Botter-Carvalho et al. } \\
\text { (2014) }\end{array}$ & EU & Un-veg & 1 & 6 & $<1$ & $\mathrm{QR}$ & $\mathrm{N}$ & 0 & $1200-2400$ & NR & - \\
\hline Guevara et al. (2014) & EU, B & Veg & 6 & 36 & $>5$ & SR & $\mathrm{N}$ & 0 & NR & NR & - \\
\hline Current study & & $\begin{array}{l}\text { Veg }+ \\
\text { Un-veg }\end{array}$ & 1 & 28 & $<1$ & SR & $\mathrm{N}$ & $0-15$ & $150 \& 600$ & $\uparrow$ & $1-580$ \\
\hline
\end{tabular}

Appendix 2

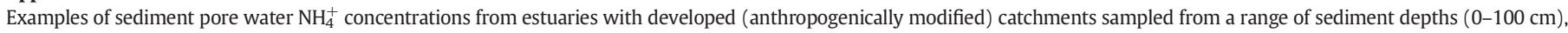
compared to those observed during this study.

\begin{tabular}{|c|c|c|c|}
\hline Source & Estuary & Country & $\mathrm{NH}_{4}^{+}(\mu \mathrm{M})$ \\
\hline Santos et al. (2014) & Tauranga & New Zealand & $6-52$ \\
\hline Cabrita and Brotas (2000) & Tagus Estuary & Portugal & $18-40$ \\
\hline Percuoco et al. (2015) & Great Bay Estuary & USA & $50-1400$ \\
\hline De Vittor et al. (2012) & Marano-Grado Lagoon & Italy & $52-900$ \\
\hline Zhang et al. (2013) & Pearl River Estuary & China & $64-321$ \\
\hline Vidal and Morgui (1995) & Alfacs Bay & Spain & $100-600$ \\
\hline Magni et al. (2014) & Shinkawa-Kasugawa Estuary & Japan & $200-500$ \\
\hline Lohrer et al. (2010) & Mahurangi Estuary & New Zealand & $257-1542$ \\
\hline Pérez-Villalona et al. (2015) & San Juan Bay Estuary & Puerto Rico & $461-572$ \\
\hline Cook et al. (2004) & Huon Estuary & Australia & 500 \\
\hline Clavero et al. (2000) & Palmones River Estuary & Spain & $500-3500$ \\
\hline Bally et al. (2004) & Seine Estuary & France & 1940 \\
\hline Gonçalves et al. (2012) & Santos-Cubatao Estuarine System & Brazil & $2495-4989$ \\
\hline \multirow[t]{2}{*}{ This study } & Application rate $150 \mathrm{~g} \mathrm{~N} \mathrm{~m}^{-2}$ & & $64-10,275$ \\
\hline & Application rate $600 \mathrm{~g} \mathrm{~N} \mathrm{~m}^{-2}$ & & $11-18,842$ \\
\hline
\end{tabular}

\section{References}

Abreu, P.C., Costa, C.S.B., Bemvenuti, C., Odebrecht, C., Graneli, W., Anesio, A.M., 2006 Eutrophication processes and trophic interactions in a shallow estuary: preliminary results based on stable isotope analysis $\left(\delta^{13} \mathrm{C}\right.$ and $\left.\delta^{15} \mathrm{~N}\right)$. Estuar. Coasts 29 , 277-285.

Aller, R.C., 1988. Benthic fauna and biogeochemical processes in marine sediments: the role of burrow structures. In: Blackburn, T.H., Sorensen, J. (Eds.), Nitrogen Cycling in Coastal Marine Environments. John Wiley \& Sons, pp. 301-338.

Arar, E., Collins, G., 1997. In vitro determination of chlorophyll a and pheophytin a in marine and freshwater algae by fluorescence. National Exposure Research Laboratory. Environmental Protection Agency, Cincinnati, U.S.

Armitage, A.R., Frankovich, T.A., Heck, K.L., Fourqurean, J.W., 2005. Experimental nutrient enrichment causes complex changes in seagrass, microalgae, and macroalgae community structure in Florida Bay. Estuaries 28, 422-434.
Armitage, A.R., Frankovich, T.A., Fourqurean, J.W., 2006. Variable responses within epiphytic and benthic microalgal communities to nutrient enrichment. Hydrobiologia 569, 423-435.

Bally, G., Mesnage, V., Deloffre, J., Clarisse, O., Lafite, R., Dupont, J.-P., 2004. Chemical characterization of porewaters in an intertidal mudflat of the Seine estuary: relationship to erosion-deposition cycles. Mar. Pollut. Bull. 49, 163-173.

Bertics, V., Sohm, J., Treude, T., Chow, C., Capone, D., Fuhrman, J., Ziebis, W., 2010 Burrowing deeper into benthic nitrogen cycling: the impact of bioturbation on nitrogen fixation coupled to sulfate reduction. Mar. Ecol. Prog. Ser. 409, 1-15.

Blackburn, T.H., Henriksen, K., 1983. Nitrogen cycling in different types of sediments from Danish waters. Limnol. Oceanogr. 28, 477-493.

Botter-Carvalho, M.L., Carvalho, P.V.V.C., Valença, A.P.M.C., Santos, P.J.P., 2014. Estuarine macrofauna responses to continuous in situ nutrient addition on a tropical mudflat. Mar. Pollut. Bull. 83, 214-223.

Braeckman, U., Foshtomi, M.Y., Van Gansbeke, D., Meysman, F., Soetaert, K., Vincx, M. Vanaverbeke, J., 2014. Variable importance of macrofaunal functional biodiversity for biogeochemical cycling in temperate coastal sediments. Ecosystems 17, 720-737. 
Bulthuis, D.A., Woelkerling, W.J., 1981. Effects of in situ nitrogen and phosphorus enrichment of the sediments on the seagrass Heterozostera tasmanica (Martens ex Aschers.) den Hartog in Western Port, Victoria, Australia. J. Exp. Mar. Biol. Ecol. 53, 193-207.

Bulthuis, D.A., Axelrad, D.M., Mickelson, M.J., 1992. Growth of the seagrass Heterozosterd tasmanica limited by nitrogen in Port Phillip Bay, Australia. Mar. Ecol. Prog. Ser. 89 269-275.

Burnham, K.P., Anderson, D.R., 2002. Model Selection and Multimodel Inference: A Pratical Information-Theoretic Approach. Springer, New York, NY.

Cabrita, M.T., Brotas, V., 2000. Seasonal variation in denitrification and dissolved nitrogen fluxes in intertidal sediments of the Tagus estuary, Portugal. Mar. Ecol. Prog. Ser. 202, 51-65.

Cebrian, J., Stutes, A.L., Phipps, S., Stutes, J.P., Christiaen, B., Pennock, J.R., 2012. Effects of short-term sediment nutrient enrichment and grazer (Neritina reclivata) removal on sediment microalgae in a shallow eutrophic estuary (Alabama, USA). Rev. De Biol. Trop. 60, 1687-1706.

Ceccherelli, G., Cinelli, F., 1997. Short-term effects of nutrient enrichment of the sediment and interactions between the seagrass Cymodocea nodosa and the introduced green alga Caulerpa taxifolia in a Mediterranean bay. J. Exp. Mar. Biol. Ecol. 217, 165-177.

Clarke, K.R., Gorley, R.N., 2015. PRIMER v7: User Manual/Tutorial. PRIMER-E, Plymouth (296 pp).

Clavero, V., Izquierdo, J.J., Fernandez, J.A., Niell, F.X., 2000. Seasonal fluxes of phosphate and ammonium across the sediment-water interface in a shallow small estuary (Palmones River, southern Spain). Mar. Ecol. Prog. Ser. 198, 51-60.

Cook, P.L.M., Revill, A.T., Butler, E.C.V., Eyre, B.D., 2004. Carbon and nitrogen cycling on intertidal mudflats of a temperate Australian estuary. II. Nitrogen cycling. Mar. Ecol. Prog. Ser. 280, 39-54.

Costanza, R., d'Arge, R., de Groot, R., Farber, S., Grasso, M., Hannon, B., Limburg, K., Naeem, S., O'Neill, R.V., Paruelo, J., Raskin, R.G., Sutton, P., van den Belt, M., 1997. The value of the world's ecosystem services and natural capital. Nature 387, 253-260.

De Vittor, C., Faganeli, J., Emili, A., Covelli, S., Predonzani, S., Acquavita, A., 2012. Benthic fluxes of oxygen, carbon and nutrients in the Marano and Grado Lagoon (northern Adriatic Sea, Italy). Estuar. Coast. Shelf Sci. 113, 57-70.

Dennison, W.C., Aller, R.C., Alberte, R.S., 1987. Sediment ammonium availability and eelgrass (Zostera marina) growth. Mar. Biol. 94, 469-477.

Eberhardt, L.L., Thomas, J.M., 1991. Designing environmental field studies. Ecol. Monogr. $61,53-73$.

Ellis, J., Schneider, D.C., 2008. Spatial and temporal scaling in benthic ecology. J. Exp. Mar Biol. Ecol. 366, 92-98

Erftemeijer, P.L.A., Stapel, J., Smekens, M.J.E., Drossaert, W.M.E., 1994. The limited effect of in-situ phosphorus and nitrogen additions to seagrass beds on carbonate and terrigenous sediments in South Sulawesi, Indonesia. J. Exp. Mar. Biol. Ecol. 182, $123-140$.

Feller, I.C., 1995. Effects of nutrient enrichment on growth and herbivory of dwarf red mangrove (Rhizophora mangle). Ecol. Monogr. 65, 477-505.

Ferdie, M., Fourqurean, J.W., 2004. Responses of seagrass communities to fertilization along a gradient of relative availability of nitrogen and phosphorus in a carbonate environment. Limnol. Oceanogr. 49, 2082-2094.

Fitch, J.E., Crowe, T.P., 2012. Combined effects of inorganic nutrients and organic enrichment on intertidal benthic macrofauna: an experimental approach. Mar. Ecol. Prog. Ser. 461, 59-70.

Flothmann, S., Werner, I., 1992. Experimental eutrophication on an intertidal sandflat - ef fects on microphytobenthos, meiofauna and macrofauna. In: Colombo, G., Ferrari, I. Ceccherelli, V.U., Rossi, R. (Eds.), Marine Eutrophication and Population Dynamics. Olsen \& Olsen, Fredensborg, pp. 93-100.

Fonseca, M.S., Kenworthy, W.J., Courtney, F.X., Hall, M.O., 1994. Seagrass planting in the southeastern United States: methods for accelerating habitat development. Restor Ecol. 2, 198-212.

Gil, M., Armitage, A.R., Fourqurean, J.W., 2006. Nutrient impacts on epifaunal density and species composition in a subtropical seagrass bed. Hydrobiologia 569 437-447.

Gilbert, F., Stora, G., Bonin, P., 1998. Influence of bioturbation on denitrification activity in Mediterranean coastal sediments: an in situ experimental approach. Mar. Ecol. Prog. Ser. 163, 99-107.

Glud, R.N., 2008. Oxygen dynamics of marine sediments. Mar. Biol. Res. 4, 243-289.

Gonçalves, W.F.O., Luiz-Silva, W., Machado, W., Nizoli, E.C., Santelli, R.E., 2012. Geochemistry of intertidal sediment pore waters from the industrialized Santos-Cubatão Estuarine System, SE Brazil. An. Acad. Bras. Cienc. 84, 427-442.

Guevara, R., Ikenaga, M., Dean, A., Pisani, C., Boyer, J., 2014. Changes in sediment bacteria community in response to long-term nutrient enrichment in a subtropical seagrassdominated estuary. Microbial Ecol. 68, 427-440.

Herbert, R.A., 1999. Nitrogen cycling in coastal marine ecosystems. FEMS Microbiol. Rev. 23, 563-590.

Hewitt, J.E., Thrush, S.F., Dayton, P.K., Bonsdorff, E., 2007. The effect of spatial and temporal heterogeneity on the design and analysis of empirical studies of scale-dependent systems. Am. Nat. 169, 398-408.

Hohaia, A., Vopel, K., Pilditch, C.A., 2013. Thin terrestrial sediment deposits on intertida sandflats: effects on pore water solutes and juvenile bivalve burial behaviour. Biogeosci. Discuss. 10, 14835-14860.

Howarth, R.W., Marino, R., 2006. Nitrogen as the limiting nutrient for eutrophication in coastal marine ecosystems: evolving views over three decades. Limnol. Oceanogr. 51, 364-376.

Howarth, R., Chan, F., Conley, D.J., Garnier, J., Doney, S.C., Marino, R., Billen, G., 2011. Coupled biogeochemical cycles: eutrophication and hypoxia in temperate estuaries and coastal marine ecosystems. Front. Ecol. Environ. 9, 18-26.

Huettel, M., Roy, H., Precht, E., Ehrenhauss, S., 2003. Hydrodynamical impact on biogeochemical processes in aquatic sediments. Hydrobiologia 494, 231-236.
Kenworthy, W.J., Fonseca, M.S., 1992. The use of fertilizer to enhance growth of transplanted seagrasses Zostera marina L. and Halodule wrightii Aschers. J. Exp. Mar. Biol. Ecol. 163, 141-161.

Kenworthy, W.J., Zieman, J., Thayer, G., 1982. Evidence for the influence of seagrasses on the benthic nitrogen cycle in a coastal plain estuary near Beaufort, North Carolina (USA). Oecologia 54, 152-158.

Kohler, K., Gill, S., 2006. Coral point count with Excel extensions (CPCe): a Visual Basic program for the determination of coral and substrate coverage using random point count methodology. Comput. Geosci. 32, 1259-1269.

Kristensen, E., Jensen, M.H., Aller, R.C., 1991. Direct measurement of dissolved inorganic nitrogen exchange and denitrification in individual polychaete (Nereis-virens) burrows. J. Mar. Res. 49, 355-377.

Laverock, B., Gilbert, J.A., Tait, K., Osborn, A.M., Widdicombe, S., 2011. Bioturbation: impact on the marine nitrogen cycle. Biochem. Soc. Trans. 39, 315-320.

Lever, M.A., Valiela, I., 2005. Response of microphytobenthic biomass to experimental nutrient enrichment and grazer exclusion at different land-derived nitrogen loads. Mar. Ecol. Prog. Ser. 294, 117-129.

Levin, L.A., Liu, K.-K., Emeis, K.-C., Breitburg, D.L., Cloern, J., Deutsch, C., Giani, M., Goffart, A., Hofmann, E.E., Lachkar, Z., Limburg, K., Liu, S.-M., Montes, E., Naqvi, W., Ragueneau, O., Rabouille, C., Sarkar, S.K., Swaney, D.P., Wassman, P., Wishner, K.F., 2015. Comparative biogeochemistry-ecosystem-human interactions on dynamic continental margins. J. Mar. Syst. 141, 3-17.

Lohrer, A.M., Thrush, S.F., Hewitt, J.E., Berkenbusch, K., Ahrens, M., Cummings, V.J., 2004. Terrestrially derived sediment: response of marine macrobenthic communities to thin terrigenous deposits. Mar. Ecol. Prog. Ser. 273, 121-138.

Lohrer, A.M., Halliday, N.J., Thrush, S.F., Hewitt, J.E., Rodil, I.F., 2010. Ecosystem functioning in a disturbance-recovery context: contribution of macrofauna to primary production and nutrient release on intertidal sandflats. J. Exp. Mar. Biol. Ecol. 390, 6-13.

Lomstein, B.A., Blackburn, T.H., Henriksen, K., 1989. Aspects of nitrogen and carbon cycling in the northern Bering Shelf sediment. I. The significance of urea turnover in the mineralization of $\mathrm{NH}_{4}^{+}$. Mar. Ecol. Prog. Ser. 57, 237-247.

Magni, P., Como, S., Montani, S., Tsutsumi, H., 2014. Interlinked seasonal variation in biogenic nutrient fluxes and pore-water nutrient concentrations in intertidal sediments. Mar. Biol. 161, 2767-2779

McGlathery, K.J., 1995. Nutrient and grazing influences on a subtropical seagrass community. Mar. Ecol. Prog. Ser. 122, 239-252.

Morris, L., Keough, M.J., 2003a. Testing the effects of nutrient additions on mudflat macroinfaunal assemblages in the presence and absence of shorebird predators. Mar. Freshw. Res. 54, 859-874.

Morris, L., Keough, M.J., 2003b. Variation in the response of intertidal infaunal invertebrates to nutrient additions: field manipulations at two sites within Port Phillip Bay, Australia. Mar. Ecol. Prog. Ser. 250, 35-49.

Murray, L., Dennison, W.C., Michael Kemp, W., 1992. Nitrogen versus phosphorus limitation for growth of an estuarine population of eelgrass (Zostera marina L.). Aquat. Bot. $44,83-100$

O'Brien, A.L., Volkenborn, N., van Beusekom, J., Morris, L., Keough, M.J., 2009. Interactive effects of porewater nutrient enrichment, bioturbation and sediment characteristics on benthic assemblages in sandy sediments. J. Exp. Mar. Biol. Ecol. 371, 51-59.

O'Brien, A.L., Morris, L., Keough, M.J., 2010. Multiple sources of nutrients add to the complexities of predicting marine benthic community responses to enrichment. Mar. Freshw. Res. 61, 1388-1398.

O'Gorman, E.J., Fitch, J.E., Crowe, T.P., 2012. Multiple anthropogenic stressors and the structural properties of food webs. Ecology 93, 441-448.

Olsen, Y.S., Valiela, I., 2010. Effect of sediment nutrient enrichment and grazing on turtle grass Thalassia testudinum in Jobos Bay, Puerto Rico. Estuar. Coasts 33, 769-783.

Orth, R.J., 1977. Effect of nutrient enrichment on growth of the eelgrass Zostera marina in the Chesapeake Bay, Virginia, USA. Mar. Biol. 44, 187-194.

Parker, J.G., 1983. A comparison of methods used for the measurement of organic matter in marine sediment. Chem. Ecol. 1, 201-209.

Pedersen, M.F., 1995. Nitrogen limitation of photosynthesis and growth: comparison across aquatic plant communities in a Danish Estuary (Roskilde Fjord). Ophelia 41, 261-272.

Percuoco, V.P., Kalnejais, L.H., Officer, L.V., 2015. Nutrient release from the sediments of the Great Bay Estuary, N.H. USA. Estuar. Coast. Shelf Sci. 161, 76-87.

Perez, M., Romero, J., Duarte, C.M., Sand-Jensen, K., 1991. Phosphorus limitation of Cymodocea nodosa growth. Mar. Biol. 109, 129-133.

Pérez-Villalona, H., Cornwell, J.C., Ortiz-Zayas, J.R., Cuevas, E., 2015. Sediment denitrification and nutrient fluxes in the San José Lagoon, a tropical lagoon in the highly urbanized San Juan Bay Estuary, Puerto Rico. Estuar. Coasts 38, 1-20.

Piceno, Y.M., Lovell, C.R., 2000. Stability in natural bacterial communities: I. Nutrient addition effects on rhizosphere diazotroph assemblage composition. Microb. Ecol. 39, $32-40$.

Piehler, M.F., Currin, C.A., Hall, N.S., 2010. Estuarine intertidal sandflat benthic microalgal responses to in situ and mesocosm nitrogen additions. J. Exp. Mar. Biol. Ecol. 390, 99-105.

Posey, M., Powell, C., Cahoon, L., Lindquist, D., 1995. Top-down vs bottom up control of benthic community composition on an intertidal tideflat. J. Exp. Mar. Biol. Ecol. 185, 19-31.

Posey, M.H., Alphin, T.D., Cahoon, L., Lindquist, D., Becker, M.E., 1999. Interactive effects of nutrient additions and predation on infaunal communities. Estuaries 22, 785-792.

Posey, M.H., Alphin, T.D., Cahoon, L.B., Lindquist, D.G., Mallin, M.A., Nevers, M.B., 2002. Top-down versus bottom-up limitation in benthic infaunal communities: direct and indirect effects. Estuaries 25, 999-1014.

Posey, M.H., Alphin, T.D., Cahoon, L., 2006. Benthic community responses to nutrient enrichment and predator exclusion: influence of background nutrient concentrations and interactive effects. J. Exp. Mar. Biol. Ecol. 330, 105-118. 
Powell, G.V.N., Kenworthy, J.W., Fourqurean, J.W., 1989. Experimental evidence for nutrient limitation of seagrass growth in a tropical estuary with restricted circulation. Bull. Mar. Sci. 44, 324-340.

Pratt, D.R., Lohrer, A.M., Pilditch, C.A., Thrush, S.F., 2013. Changes in ecosystem function across sedimentary gradients in estuaries. Ecosystems 17, 182-194.

Pratt, D.R., Lohrer, A.M., Thrush, S.F., Hewitt, J.E., Townsend, M., Cartner, K., Pilditch, C.A., Harris, R.J., van Colen, C., Rodil, I.F., 2015. Detecting subtle shifts in ecosystem functioning in a dynamic estuarine environment. PLoS One 10, e0133914.

Pulich Jr., W.M., 1985. Seasonal growth dynamics of Ruppia maritima L.s.l. and Halodule wrightii Aschers. In Southern Texas and evaluation of sediment fertility status. Aquat. Bot. 23, 53-66.

Rabalais, N.N., Cai, W.-J., Carstensen, J., Conley, D.J., Fry, B., Hu, X., Quiñones-Rivera, Z., Rosenberg, R., Slomp, C.P., Turner, R.E., Voss, M., Wissel, B., Zhang, J., 2014. Eutrophication-driven deoxygenation in the coastal ocean. Oceanography 27. 172-183.

Santos, P.J.P., Botter-Carvalho, M.L., Nascimento-Júnior, A.B., Marinho, R.G.C., Carvalho, P.V.V.C., Valença, A.P.M.C., 2009. Response of estuarine meiofauna assemblage to effects of fertilizer enrichment used in the sugar cane monoculture. Pernambuco, Brazil. Braz. J. Oceanogr. 57, 43-55.

Santos, I.R., Eyre, B.D., Huettel, M., 2012. The driving forces of porewater and groundwater flow in permeable coastal sediments: a review. Estuar. Coast. Shelf Sci. 98, 1-15.

Santos, I.R., Bryan, K.R., Pilditch, C.A., Tait, D.R., 2014. Influence of porewater exchange on nutrient dynamics in two New Zealand estuarine intertidal flats. Mar. Chem. 167, 57-70.

Short, F.T., Dennison, W.C., Capone, D.G., 1990. Phosphorus-limited growth of the tropical seagrass Syringodium filiforme in carbonate sediments. Mar. Ecol. Prog. Ser. 62. 169-174.

Singer, J.K., Anderson, J.B., Ledbetter, M.T., McCave, I.N., Jones, K.P.N., Wright, R., 1988. An assessment of analytical techniques for the size analysis of fine-grained sediments. J. Sediment. Res. 58, 534-543.

Snelgrove, P.V.R., Thrush, S.F., Wall, D.H., Norkko, A., 2014. Real world biodiversityecosystem functioning: a seafloor perspective. Trends Ecol. Evol. 29, 398-405.

StatSoft Inc., 2012. STATISTICA (Data Analysis Software System), Version 11. 11 ed. www. statsoft.com.

Stutes, A.L., Cebrian, J., Corcoran, A.A., 2006. Effects of nutrient enrichment and shading on sediment primary production and metabolism in eutrophic estuaries. Mar. Ecol. Prog. Ser. 312, 29-43.

Tay, H.W., Bryan, K.R., Pilditch, C.A., 2013. Dissolved inorganic nitrogen concentrations in an estuarine tidal flat. In: Conley, D.C., Masselink, G., Russell, P.E., O'Hare, T.J. (Eds.) 12th International Coastal Symposium. Plymouth University, England, pp. 135-140.

Teal, L., Bulling, M., Parker, E., Solan, M., 2008. Global patterns of bioturbation intensity and mixed depth of marine soft sediments. Aquat. Biol. 2, 207-218.
Thrush, S.F., Cummings, V.J., Dayton, P.K., Ford, R., Grant, J., Hewitt, J.E., Hines, A.H., Lawrie, S.M., Pridmore, R.D., Legendre, P., McArdle, B.H., Schneider, D.C., Turner, S.J., Whitlatch, R.B., Wilkinson, M.R., 1997. Matching the outcome of small-scale density manipulation experiments with larger scale patterns: an example of bivalve adult/juvenile interactions. J. Exp. Mar. Biol. Ecol. 216, 153-169.

Thrush, S.F., Hewitt, J.E., Parkes, S., Lohrer, A.M., Pilditch, C., Woodin, S.A., Wethey, D.S. Chiantore, M., Asnaghi, V., De Juan, S., Kraan, C., Rodil, I., Savage, C., Van Colen, C. 2014. Experimenting with ecosystem interaction networks in search of threshold potentials in real-world marine ecosystems. Ecology 95, 1451-1457.

Udy, J.W., Dennison, W.C., 1997. Growth and physiological responses of three seagrass species to elevated sediment nutrients in Moreton Bay, Australia. J. Exp. Mar. Biol. Ecol. 217, 253-277.

van Lent, F., Verschuure, J.M., van Veghel, M.L.J., 1995. Comparative study on populations of Zostera marina L. (eelgrass): in situ nitrogen enrichment and light manipulation. J. Exp. Mar. Biol. Ecol. 185, 55-76.

Vanderborght, J.-P., Billen, G., 1975. Vertical distribution of nitrate concentration in interstitial water of marine sediments with nitrification and denitrification. Limnol. Oceanogr. 20, 953-961.

Vetter, E.W., 1996. Enrichment experiments and infaunal population cycles on a Southern California sand plain: response of the leptostracan Nebalia daytoni and other infauna. Mar. Ecol. Prog. Ser. 137, 83-93.

Vidal, M., Morgui, J.-A., 1995. Short-term pore water ammonium variability coupled to benthic boundary layer dynamics in Alfacs Bay, Spain (Ebro Delta, NW Mediterranean). Mar. Ecol. Prog. Ser. 118, 229-236.

Williams, S.L., 1987. Competition between the seagrasses Thalassia testudinum and Syringodium filiforme in a Caribbean lagoon. Mar. Ecol. Prog. Ser. 35, 91-98.

Williams, S.L., 1990. Experimental studies of Caribbean seagrass bed development. Ecol. Monogr. 60, 449-469.

Williams, S.L., Ruckelshaus, M.H., 1993. Effects of nitrogen availability and herbivory on eelgrass (Zostera marina) and epiphytes. Ecology 74, 904-918.

Woodin, S.A., Wethey, D.S., Hewitt, J.E., Thrush, S.F., 2012. Small scale terrestrial clay deposits on intertidal sandflats: behavioral changes and productivity reduction. J. Exp. Mar. Biol. Ecol. 413, 184-191.

Worm, B., Reusch, T.B.H., Lotze, H.K., 2000. In situ nutrient enrichment: methods for marine benthic ecology. Int. Rev. Hydrobiol. 85, 359-375.

Zhang, L., Wang, L., Yin, K., Lü, Y., Zhang, D., Yang, Y., Huang, X., 2013. Pore water nutrient characteristics and the fluxes across the sediment in the Pearl River estuary and adjacent waters, China. Estuar. Coast. Shelf Sci. 133, 182-192. 